\title{
KONTEN TULISAN PESERTA DIDIK PADA PEMBELAJARAN BIOLOGI BERBASIS MASALAH
}

\section{STUDENT'S CONTENT WRITING IN BIOLOGY PROBLEM BASED LEARNING}

\author{
HILDA RAHMAWATI, SRI WIDORETNO, DEWI PUSPITA SARI \\ Program Studi Pendidikan Biologi \\ Fakultas Keguruan dan Ilmu Pendidikan \\ Universitas Sebelas Maret \\ J1. Ir. Sutami 36 A, Surakarta, 57126, Indonesia \\ *Corresponding Author: dadydud@gmail.com
}

Manuscript received : 14 Juni 2016 Revision accepted: 15 Agustus 2016

\begin{abstract}
The research aims to improve the quality of student's content writing in biology through implementation of Problem Based Learning (PBL) model. The research is a Classroom Action Researc carried out for 3 cycles. Subjects of this research were students of class XI MIPA 4 SMA N 7 Surakarta with the number of 31 learners. The research data was collected through writing documentation, observation and interviews. The validity of the data is performed using the technique of triangulation method. The research using qualitative descriptive analysis techniques. The results of the analysis of quality students content writing in the pre-cycle is 0 ; cycle 1 identified a score of 2, 3 and 4; 2 cycles identified a score of 2, 3, 4 and 5; score 3 identified a score of 1,2, 3, 4 and 5. All quality content writing cycle 1 to cycle 3 are at level 1 in the category of writing skills.
\end{abstract}

Keywords: PBL, quality of content writing, level writing skills, content writing score

\section{PENDAHULUAN}

Writing skills merupakan keterampilan hidup yang memiliki tingkat kompleksitas paling tinggi dibandingkan keterampilan berbahasa yang lain (Javed, Juan, \& Nazli, 2013). Writing skills menurut Mclean, et al. (2012), dibagi menjadi 2 aspek, yakni konten dan konteks tulisan. Konten tulisan fokus pada tujuan penulisan dan kesesuaian tulisan dengan pembaca. Konten tulisan secara spesifik merupakan cara mendemonstrasikan pengetahuan atau materi pembelajaran dengan baik melalui bahasa spesifik yang dikomunikasikan secara tertulis (Huang, Berg, Siegrist, \& Damsr, 2015).

Konten tulisan sebagai komponen aspek writing skills divisualisasikan dalam bentuk tulisan yang diobservasi, dikumpulkan, dan diukur secara sistematis selama proses pembelajaran (Rad, Khojasteh, \& Kafipour, 2014). Proses pembelajaran diobservasi untuk mengetahui kualitas konten tulisan peserta didik. Hasil observasi menunjukkan bahwa dari 31 peserta didik dalam kelas, hanya teridentifikasi 11 tulisan oleh 11 peserta didik berupa catatan harian.

Catatan harian disusun dengan menyalin slide powerpoint guru dan secara umum memiliki konten yang sama, sehingga penilaian terhadap kualitas konten tulisan tidak dapat dilakukan. Tulisan peserta didik yang tidak dapat dinilai kualitas kontennya menunjukkan bahwa konten tulisan tidak dapat dianalisis atau menunjukkan hasil 0. Menurut Rezaei \& Manzari (2011), tulisan peserta didik Sekolah Menengah Atas (SMA) ratarata berada pada tingkat rendah dilihat dari aspek konten, pengorganisasian, bahasa, dan kosakata. Tulisan cenderung berada pada tingkat rendah karena peserta didik kurang mendapatkan latihan membuat tulisan secara baik dan benar. Berdasarkan hasil observasi kualitas konten tulisan peserta didik yang tidak dapat dianalisis, menunjukkan bahwa peserta didik kurang mendapatkan latihan dalam menyusun tulisan, sehingga kualitas konten tulisannya rendah.

Kualitas konten tulisan peserta didik ditingkatkan melalui konstribusi guru dalam pengayaan literatur, pengembangan keterampilan eksplorasi aspek linguistik dan peningkatan performa peserta didik untuk menghasilkan tulisan (Huang, et al., 2015). Kegiatan menghasilkan tulisan memiliki keterkaitan yang sangat erat dengan kemampuan berpikir seseorang, menurut Kellog (2008), seorang pemikir yang substansif memiliki kemampuan untuk menyusun tulisan dengan baik. Tulisan sebagai produk pembelajaran dan wujud keterapilan komunikasi tertulis yang efektif disusun melalui proses berfikir kritis (Han, et al., 2014). Berpikir kritis adalah usaha untuk mencari solusi dari sebuah permasalahan (Dwijananti \& Yulianti, 2010).

Permasalahan ditemukan oleh peserta didik melalui kasus dalam kehidupan sehari-hari yang 
bersifat ill-structure. Kasus yang bersifat illstructure dijabarkan menjadi permasalahan yang dihubungkan dengan konsep materi untuk merumuskan masalah sesuai topik dan mengomunikasikannya secara tertulis dalam kelas (Chakravarthi, 2010). Kegiatan perumusan masalah sesuai topik teridentifikasi dalam fase meeting the problem.

Permasalahan sesuai topik memerlukan pemecahan melalui kegiatan kelompok, meliputi kegiatan mengumpulkan informasi, berdiskusi, membuat jawaban sementara, membuat rencana kegiatan untuk menyelesaikan masalah, dan mencoba melaksanakan kegiatan yang telah direncanakan (Fakriyah, 2014; Çakıroğlu, 2014). Hasil pemecahan masalah ditulis dalam laporan yang mencakup produk kegiatan berpikir kritis (Demirbag \& Gunel, 2014). Kegiatan pemecahan masalah melalui proses berpikir kritis teridentifikasi dalam fase problem analysis and learning issues.

Hasil pemecahan masalah selanjutnya disimpulkan oleh peserta didik sebagai hasil pemikiran solusi, hasil analisis dan penalaran serta hasil belajar mandiri (Sockalingam \& Schmidt, 2011) yang divisualisasikan dalam bentuk tulisan kesimpulan kelompok. Kesimpulan kelompok yang dirumuskan oleh peserta didik merupakan hasil dari fase discovery and reporting.

Tulisan peserta didik sebagai produk pembelajaran dan wujud komunikasi secara tertulis dijadikan sebagai modal kegiatan presentasi dan refleksi yang memungkinkan terjadinya perubahan terhadap hasil kesimpulan masing-masing kelompok (Chakravarthi, 2010; Demirbag \& Gunel, 2014). Kegiatan presentasi dan refleksi teridentifikasi dalam fase solution presentation and reflection.

Kegiatan presentasi dan refleksi membangun pengetahuan peserta didik yang memerukan pengujian melalui assessment/evaluasi. Evaluasi dapat diberikan melalui pemberian soal essay danjawaban diajukan melalui tulisan. Kegiatan evaluasi terakomodasi dalam fase overview, integration and evaluation.

Tulisan disusun melalui proses berpikir kritis terakomodasi dalam 5 fase model Problem Based Learning (PBL). PBL terdiri dari 5 fase yaitu: meeting the problem, problem analysis and learning issues, discovery and reporting, solution presentation and reflection, overview integration and evaluation (Tan, 2003).

Problem Based Learning (PBL) merupakan model pembelajaran yang membangun kemampuan berpikir kritis peserta didik untuk mencari solusi dari pemasalahan yang ada berdasarkan pengetahuan dan konsep materi pembelajaran (Chakravarthi, 2010; Prayekti, 2016). Materi pembelajaran dibahas secara berkelompok untuk mencari solusi dari permasalahan yang selanjutnya dikomunikasikan dalam kelas (Chakravarthi, 2010), baik dalam bentuk oral maupun tulisan. $P B L$ menurut Prayekti (2016), terdiri dari tahapantahapan yang memfasilitasi peserta didik untuk aktif dalam kegiatan pembelajaran sehingga mampu meningkatkan otonomi pembelajaran, memotivasi, dan meningkatkan kemampuan pemecahan masalah serta keterampilan komunikasi, baik komunikasi secara oral maupun tulisan.

Penelitian bertujuan untuk meningkatkan kualitas konten tulisan peserta didik pada pelajaran biologi di kelas XI MIPA 4 SMA Negeri 7 Surakarta.

\section{METODE PENELITIAN}

Penelitian merupakan Penelitian Tindakan Kelas (PTK) yang dilaksanakan selama 3 siklus, masing-masing siklus terdiri dari tahap perencanaan, pelaksanaan, tindakan dan refleksi. Setiap siklus penelitian merupakan penerapan model $P B L$ pada submateri struktur dan fungsi organ penyusun sistem reproduksi; gametogenesis; serta ovulasi, menstrasi, fertilisasi, gestasi dan kehamilan.

Subjek penelitian adalah peserta didik kelas XI MIPA 4 SMA Negeri 7 Surakarta sejumlah 31 peserta didik. Data penelitian berupa tulisan peserta didik dan didukung data observasi tulisan serta hasil wawancara. Teknik pengumpulan data menggunakan dokumentasi tulisan peserta didik selama kegiatan pembelajaran, observasi serta wawancara. Uji validasi data dilakukan menggunakan teknik triangulasi metode.

Tulisan peserta didik diperoleh melalui Lembar Kerja Siswa (LKS) sebagai produk setiap fase $P B L$. Tulisan peserta didik dianalisis menggunakan rubrik penilaian kualitas konten tulisan menurut McLean, et al. (2012). Rubrik penilaian meliputi 5 level kategori writing skills yang masing-masing level terdiri dari 5 skor konten. Analisis data menggunakan teknik analisis deskriptif kualitatif yang mengacu pada model analisis Miles dan Huberman.

\section{HASIL DAN PEMBAHASAN}

Hasil penelitian berupa tulisan peserta didik yang diperoleh selama kegiatan pembelajaran menggunakan model $P B L$, meliputi: tulisan judul, tulisan rumusan masalah dan tulisan tujuan terakomodasi pada fase meeting the problem; tulisan rencana kegiatan dan tulisan kegiatan penyelidikan terakomodasi pada fase problem analysis and learning issues; tulisan kesimpulan kelompok terakomodasi pada fase discovery and reporting; tulisan hasil presentasi terakomodasi pada fase solutioan presentation and reflection; serta tulisan kesimpulan pembelajaran terakomodasi pada fase overview, integration and evaluation. 


\subsection{Siklus 1}

Siklus 1 dilaksanakan pada submateri struktur dan fungsi organ penyusun sistem reproduksi, diawali dengan pemunculan permasalahan illstructure tentang kasus Lesbian, Gay, Bisexual and Transgender (LGBT). Tulisan peserta didik selama siklus 1 teridentifikasi di seluruh fase $P B L$. Hasil analisis kualitas konten tulisan peserta didik siklus 1 disajikan pada Gambar 1.

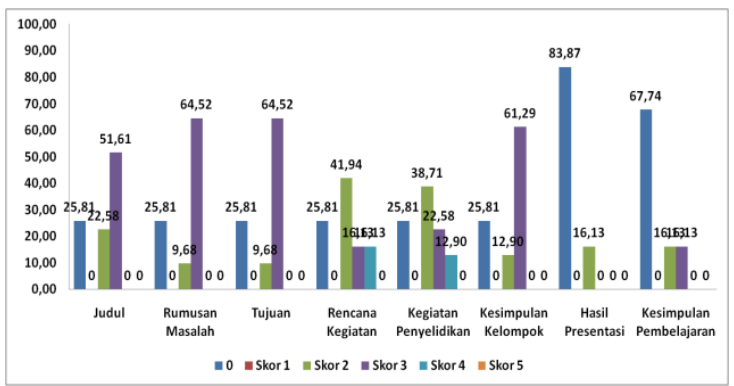

Gambar 1. Kualitas Konten Tulisan pada level 1 kategori writing skills di siklus 1

Gambar 1 menunjukkan bahwa kualitas konten tulisan peserta didik siklus 1 rata-rata berada pada skor 2 dan 3 di level 1 kategori writing skills, namun terdapat tulisan yang tidak teridentifkasi sejumlah $25,81 \%$ pada fase meeting the problem sampai dengan discovery and reporting; $83,87 \%$ pada fase solution and reflection dan $67,74 \%$ pada fase overview, integration and evaluation. Tulisan peserta didik mencapai kualitas konten tertinggi pada fase problem analysis and learning issues, yakni pada skor 4 sejumlah $16,13 \%$ di tulisan rencana kegiatan dan $12,90 \%$ di tulisan kegiatan penyelidikan.

\subsection{Siklus 2}

Siklus 2 dilaksanakan pada submateri gametogenesis, diawali dengan pemunculan permasalahan ill-structure tentang kasus kemandulan. Siklus 2 memiliki cakupan materi lebih sedikit dibandingkan siklus 1 . Tulisan peserta didik selama siklus 2 teridentifikasi pada fase meeting the problem, problem analysis and learning issues, discoveri and reporting dan overview, integration and evaluation. Tulisan tidak teridentifikasi pada fase solution presentation and reflection. Hasil analisis kualitas konten tulisan peserta didik siklus 2 disajikan pada Gambar 2.

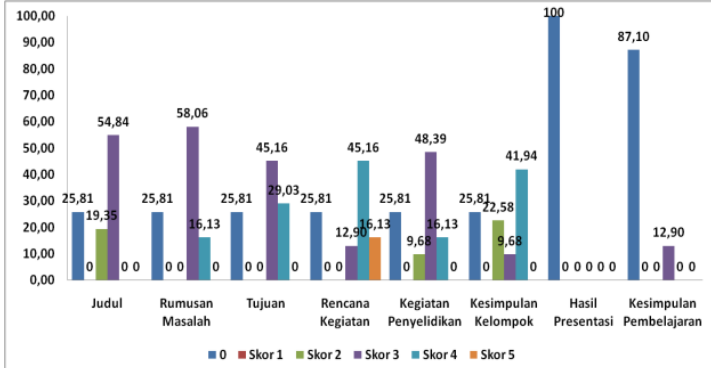

Gambar 2. Kualitas Konten Tulisan pada level 1 kategori writing skills di siklus 2

Gambar 2 menunjukkan bahwa kualitas konten tulisan peserta didik memiliki capaian skor yang berbeda-beda di setiap tulisan yang dihasilkan, namun terdapat tulisan yang tidak teridentifkasi sejumlah $25,81 \%$ pada fase meeting the problem sampai dengan discovery and reporting; $100 \%$ pada fase solution and reflection dan $87,10 \%$ pada fase overview, integration and evaluation. Tulisan tidak teridentifikasi $100 \%$ pada fase solution and reflection di siklus 2 menunjukkan bahwa tidak ada peserta didik yang menghasilkan tulisan pada kegiatan presentasi, diduga karena peserta didik lebih fokus pada komunikasi secara lisan untuk menyampaikan hasil penyelidikannya, sesuai dengan pendapat Kustijono (2011) yang menyatakan bahwa komunikasi lisan merupakan penekanan dari kegiatan presentasi.

Kualitas konten tulisan peserta didik siklus 2 terdapat pada skor 2, 3, 4 dan 5 di level 1 kategori writing skills. Skor 2 teridentifikasi 19,35\% pada tulisan judul; $9,68 \%$ pada tulisan kegiatan penyelidikan dan $22,58 \%$ pada tulisan kesimpulan kelompok. Skor 3 teridentifikasi pada seluruh aspek tulisan yang dihasilkan peserta didik dengan rata-rata capaian sebesar 30,24\%. Skor 4 teridentifikasi $16,13 \%$ pada tulisan rumusan masalah dan tulisan kegiatan penyelidikan; 29,03\% pada tulisan tujuan; $45,16 \%$ pada tulisan rencana kegiatan serta $41,4 \%$ pada tulisan kesimpulan kelompok. Skor 5 merupakan skor tertinggi yang terifdentifikasi sejumlah $16,13 \%$ pada tulisan rencana kegiatan.

\subsection{Siklus 3}

Siklus 3 dilaksanakan pada submateri ovulasi, mentruasi, fertilisasi, gestasi dan kelahiran; diawali dengan pemunculan permasalahan illstructure tentang kasus kelahiran bayi prematur kembar 5. Siklus 3 memiliki cakupan materi paling banyak dibandingkan siklus 1 dan siklus 2 . Tulisan peserta didik selama siklus 3 teridentifikasi pada fase meeting the problem, problem analysis and learning issues, discoveri and reporting dan overview, integration and evaluation. Tulisan tidak teridentifikasi pada fase solution presentation and reflection. Hasil analisis kualitas konten tulisan peserta didik siklus 3 disajikan pada Gambar 3. 


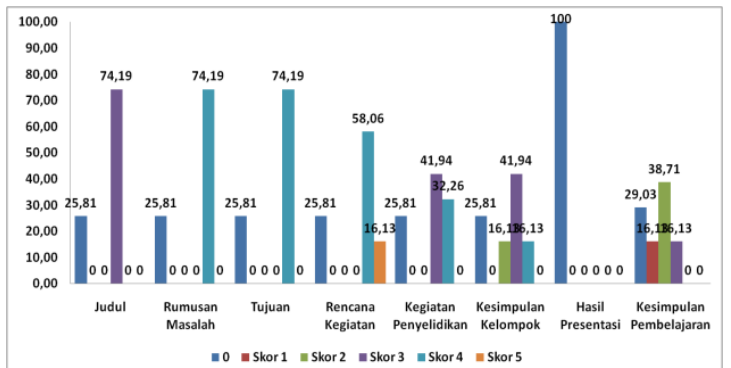

Gambar 3. Kualitas Konten Tulisan pada level 1 kategori writing skills di siklus 3

Gambar 3 menunjukkan bahwa kualitas konten tulisan peserta didik pada siklus 3 memiliki capaian yang beragam dari skor 1 sampai dengan skor 5 di level 1 kategori writing skills, namun terdapat tulisan yang tidak teridentifkasi sejumlah $25,81 \%$ pada fase meeting the problem sampai dengan discovery and reporting; $100 \%$ pada fase solution and reflection dan $29,03 \%$ pada fase overview, integration and evaluation. Tulisan tidak teridentifikasi $100 \%$ pada fase solution and reflection di siklus 3, sama seperti di siklus 2 , diduga karena peserta didik lebih fokus pada komunikasi secara lisan untuk menyampaikan hasil penyelidikannya, sesuai dengan pendapat Kustijono (2011) yang menyatakan bahwa komunikasi lisan merupakan penekanan dari kegiatan presentasi.

Tulisan peserta didik memiliki capaian kualitas konten terendah pada skor 1 sejumlah $16,13 \%$ di tulisan kesimpulan pembelajaran dan capaian tertinggi tertenggi pada skor 5 sejumlah $16,13 \%$ di tulisan rencana kegiatan. Kualitas konten tulisan didominasi oleh capaian rata-rata $21,77 \%$ pada skor 3 dan $31,85 \%$ pada skor 4 . Skor 2 terdentifikasi $16,13 \%$ pada tulisan kesimpulan kelompok dan $38,71 \%$ pada tulisan kesimpulan pembelajaran

\subsection{Perbandingan Seluruh Siklus}

Kualitas konten tulisan peserta didik mengalami peningkatan dari prasiklus sampai dengan siklus 3. Perbandingan capaian kualitas konten tulisan dari kegiatan prasiklus sampai dengan siklus 3 disajikan pada Gambar 4.

Gambar 4 menunjukkan bahwa tulisan peserta didik mengalami peningkatan kualitas konten yang cukup baik melalui penerapan model $P B L$ di siklus 1 , siklus 2 dan siklus 3 .

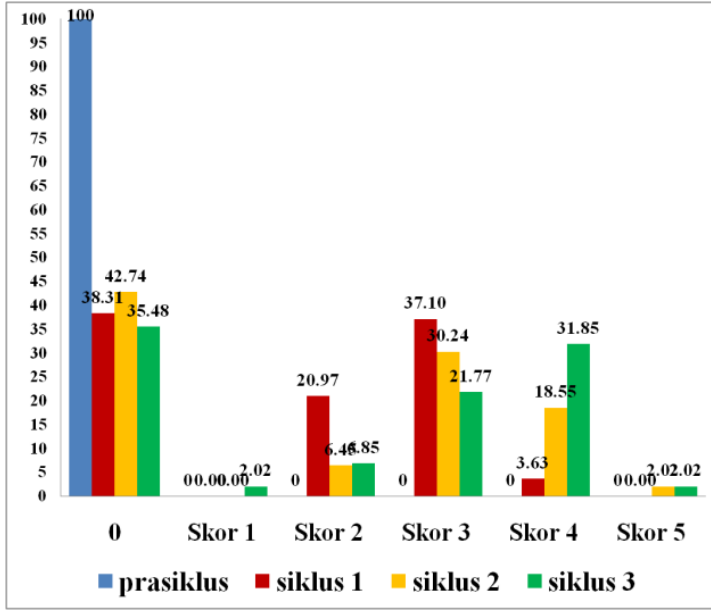

Gambar 4. Perbandingan Capaian Kualitas Konten Tulisan di Seluruh Siklus

Siklus 1 menunjukkan rata-rata capaian kualitas konten tulisan sebesar $20,97 \%$ pada skor 2; $37,10 \%$ pada skor 3 dan $3,63 \%$ pada skor 4 . Kualitas konten tulisan siklus 2 rata-rata teridentifikasi $6,45 \%$ pada skor $2 ; 30,24 \%$ pada skor $3 ; 18,55 \%$ pada skor 4 dan $2,02 \%$ pada skor 5 , sehingga menunjukkan adanya pergeseran capaian skor, yaitu: menurunnya jumlah skor 2 dan 3, serta meningkatnya jumlah skor 4 dan 5 . Kualitas konten tulisan siklus 3 rata-rata teridentifikasi $2,02 \%$ pada skor $1 ; 6,85 \%$ pada skor $2 ; 21,17 \%$ pada skor 3 ; $31,85 \%$ pada skor 4 dan 2,02\% pada skor 5, sehingga menunjukkan peningkatan capaian skor 4 yang cukup signifikan dibandingkan siklus 1 dan siklus 2 .

Hasil analisis menunjukkan bahwa kualitas konten tulisan peserta didik mengalami peningkatan jumlah dan perubahan skor dari siklus 1 sampai dengan siklus 3 secara fluktuatif. Peningkatan kualitas konten tulisan peserta didik pada pembelajaran siklus 1 , siklus 2 dan siklus 3 dibandingkan dengan hasil pratindakan menunjukkan bahwa model $P B L$ mampu meningkatkan kualitas konten tulisan peserta didik. $P B L$ membangun kemampuan berpikir kritis dan keterampilan pemecahan masalah, sehingga mampu mendorong peserta didik mengembangkan kemampuan berpikir substansif untuk menghasilkan tulisan yang baik (Chakravarthi, 2010; Kellogg, 2008). Menurut Rezaei \& Manzari (2011), kemapuan menghasilkan tulisan yang baik dikembangkan melalui penerapan pembelajaran yang membimbing peserta didik untuk lebih mudah menghasilkan tulisan (writing easier), lebih sering menghasilkan tulisan (writing more), menghasilkan tulisan yang berbeda-beda (writing differently), serta menghasilkan tulisan yang lebih baik (writing better). PBL merupakan model pembelajaran yang mengakomodasi peserta didik menghasilkan tulisan di seluruh fase, meliputi: meeting the problem, problem analysis and learning issues, discovery and reporting, solution presentation and reflection, 
dan overview integration and evaluation. Tulisan disusun oleh peserta didik di setiap fase $P B L$ melalui pengadaan Lembar Kerja Siswa (LKS). LKS memfasilitasi penyusunaan tulisan sebagai proyek kerja kelompok yang menarik perhatian peserta didik dan mampu mengarahkan pada kegiatan menghasilkan tulisan (Dumitrescu, Coman, \& $\mathrm{Nu}, 2015)$.

\section{KESIMPULAN}

Penerapan model Problem Based Learning meningkatkan kualitas konten tulisan peserta didik secara efektif. Kualitas konten tulisan peserta didik 0 pada prasiklus dan meningkat di level 1 kategori writing skills pada pembelajaran siklus 1, siklus 2 dan siklus 3. Kualitas konten tulisan siklus 1 ratarata teridentifikasi $20,97 \%$ pada skor $2 ; 37,10 \%$ pada skor 3 dan 3,63\% pada skor 4 . Kualitas konten tulisan siklus 2 rata-rata teridentifikasi $6,45 \%$ pada skor $2 ; 30,24 \%$ pada skor $3 ; 18,55 \%$ pada skor 4 dan 2,02\% pada skor 5. Kualitas konten tulisan siklus 3 rata-rata teridentifikasi $2,02 \%$ pada skor $1 ; 6,85 \%$ pada skor $2 ; 21,17 \%$ pada skor $3 ; 31,85 \%$ pada skor 4 dan $2,02 \%$ pada skor 5 .

\section{DAFTAR PUSTAKA}

Çakıroğlu, Ü. (2014). Enriching Project-Based Learning Environments with Virtual Manipulatives: A Comparative Study. Eurasian Journal of Educational Research (55), 201-222.

Chakravarthi, S. (2010). Implementation of PBL Curriculum Involving Multiple Disciplines in Undergraduate Medical Education Programme. International Education Studies , 3 (1), 165-169.

Demirbag, M., \& Gunel, M. (2014). Integrating Argument-Based Science Inquiry with Modal Representations: Impact on Science Achievement, Argumentation, and Writing Skills. Educational Sciences: Theory \& Practice , 14 (1), 386-391.

Dumitrescu, C. I., Coman, M. L., \& Nu, I. -C. (2015). Improving Functional Texts Writing Skills in English as a Foreign Language. Social and Behavioral Sciences , 203, 168-172.

Dwijananti, P., \& Yulianti, D. (2010). Pengembangan Kemampuan Berpikir Kritis Mahasiswa Melalui Pembelajaran Problem Based Instruction pada Mata Kuliah Fisika Lingkungan. Jurnal Pendidikan Fisika Indonesia , 6, 108 - 114.

Fakhriyah, F. (2014). Penerapan Problem Based Learning dalam Upaya Mengembangkan Kemampuan Berpikir Kritis Mahasiswa. Jurnal Pendidikan IPA Indonesia , 3 (1), 95 - 101.

Han, N. S., Li, H. K., Sin, L. C., \& Sin, K. P. (2014). The Evaluation of Students' Written Reflection on the Learning of General Chemistry Lab Experiment. Malaysian Online Journal of Educational Science , 2 (4), 45 - 52.

Huang, J., Berg, M., Siegrist, M., \& Damsr, C. (2015). Impact of a functional linguistic approach to teacher development on content area student writing. International Journal of Applied Linguistics , 1-36.

Javed, M., Juan, W. X., \& Nazli, S. (2013). A Study of Students' Assessment in Writing Skills of the English
Language. International Journal of Instruction , 6 (2), 129-144.

Kellogg, R. T. (2008). Training writing skills: A cognitive developmental perspective. Journal of writing research, 1 (1), 1-26.

Kemmis, S., \& McTaggart, R. (2007). Participatory Action Research: Communicative Action and the Public Sphere (2nd Edition ed.). (N. K. Denzin, \& Y. S. Lincoln, Eds.) Thousand Oaks, CA: Sage.

Kustijono, R. (2011). Implementasi Student Centered Learning dalam Praktikum Fisika DasaR. Jurnal Penelitian Fisika dan Aplikasinya (JPFA) , 1 (02), 19-32.

Mclean, P., Perkins, K., Tout, D., Brewer, K., \& Wyse, L. (2012). Australian Core Skills Framework: 5 core skills, 5 levels of performance, 3 domains of communication. Australia: Australian Council for Educational Research.

Prayekti. (2016). Effects of Problem-Based Learning Model Versus Expository Model and Motivation to Achieve for Student's Physic Learning Result of Senior High School at Class Xi. Journal of Education and Practice , 7 (1), 30-37.

Rad, R., Khojasteh, L., \& Kafipour, R. (2014). The Relationship between Multiple Intelligences and Writing Skill of Medical Students in Iran. Acta Didactica Napocensia , 7 (3), 1-10.

Rezaei, M., \& Manzari, E. (2011). A Post-Process Approach: E-mail Dialogue Journal Writing and its Impact on Quality and Quantity of High School Students' Writing. Indonesian Journal of English Language Teaching , 7 (1), 19-30.

Sockalingam, N., \& Schmidt, H. G. (2011). Characteristics of Problems for Problem-Based Learning: The Students' Perspective. Interdisciplinary Journal of Problem-Based Learning , 5 (1), -.

Tan, O.-S. (2003). Problem Based Learning Innovation: Using problems to power learning in the 21st century. Singapore: Thomson Learning. 